\title{
THE COMPLEX STRUCTURE OF THE ABSOLUTE PROHIBITION OF TORTURE. COMMENTS IN THE LIGHT OF THE REGULATION OF ARTICLE 3 OF THE EUROPEAN CONVENTION ON HUMAN RIGHTS
}

\author{
A ESTRUTURA COMPLEXA DA PROIBIÇÃO ABSOLUTA DA TORTURA: COMENTÁRIOS À LUZ DO \\ REGULAMENTO DO ARTIGO 3० DA CONVENÇÃO EUROPEIA DOS DIREITOS DO HOMEM
}

Elzbieta Hanna Morawska

\begin{abstract}
The complexity indicated in the title of this paper does not refer purely to the internal structure of the prohibition of torture, but also to the obligations of States party to the ECHR that are tied to this prohibition. This is because it is not restricted to negative obligations understood as a duty on the part of the State to abstain from certain interferences by the public authorities and which was the fundamental purpose of the ECHR and as such was entered explicit into the normative structure of the freedoms and rights defined in the ECHR, but embraces - firstly - positive obligations which result in a command to take measures for the purpose of ensuring freedom from the said torture for persons under the jurisdiction of States that are party to the ECHR, both in horizontal and vertical relations, and - secondly - a procedural obligations which, year by year, is achieving an ever more autonomous position among the types of commitment resulting from the ECHR for States and the essence of which is the effective clarification of circumstances in the violation of the prohibition of torture.
\end{abstract}

Keywords: Human Rights. Torture. Ill-treatment. Positive and negative obligations.
Resumo: A complexidade indicada no título deste trabalho não se refere puramente à estrutura interna da proibição da tortura, mas também às obrigações dos Estados partes na $\mathrm{CEDH}$ que estão ligadas a esta proibição. Isso porque não se limita a uma obrigação negativa, entendida como dever do Estado de se abster de certas interferências das autoridades públicas, e que era o objectivo fundamental da $\mathrm{CEDH}$, mas abrange, notadamente, as obrigações positivas que resultam no dever de tomar medidas para garantir a liberdade em relação à tortura para as pessoas sujeitas à jurisdição dos Estados que são partes na CEDH. Por outro, implica também obrigações processuais que, ano após ano, estão a conseguir uma posição cada vez mais autónoma entre os tipos de compromissos resultantes da CEDH para os Estados e cuja essência é a clarificação efetiva das circunstâncias da violação à proibição da tortura.

Palavras-chave: Direitos Humanos. Tortura. Maus tratos. Obrigações positivas e negativas.

\footnotetext{
"PhD in Law of the University of Warsaw; Assistant Professor at the Department of Human Rights Protection and International Humanitarian Law, Institute of International Law, the European Union and International Relations, Faculty of Law and Administration, Cardinal Stefan Wyszyński University of Warsaw, Poland. e.morawska@uksw.edu.pl
} 


\section{Introduction}

One of the most important instruments via which the Council of Europe (hereinafter: $\mathrm{CoE}$ ) carries out its statutory goals of protecting human rights and the rule of law ${ }^{1}$ is the Convention for the Protection of Human Rights and Fundamental Freedoms, usually referred to as the European Convention on Human Rights (hereinafter: ECHR). This was the CoE's first multilateral treaty and at the same time the only one of many CoE treaties where a mechanism was anticipated for investigating inter-state issues or individual complaints (Drzemczewski, 2001, pp. 158-163).

It is a well-known fact that the catalogue of human rights and freedoms defined in the ECHR has essentially been limited to selected personal human rights and fundamental political freedoms, while those rights for which regulation aroused the greatest reservations, in other words the right to property, education and free elections, ${ }^{2}$ were transferred to the supplementary Protocol $1 .^{3}$ The initiators of the ECHR focused on those human rights considered as significant elements of the foundations of European democracies. The prohibition of torture has a special place among them, and is defined by Article 3 of the ECHR, stating that "No one shall be subjected to torture or to inhuman or degrading treatment or punishment."

1. Since 1998, Article 3 of the ECHR has borne the title Prohibition of torture. ${ }^{4}$ Specific conduct, acknowledged as that demanding the fullest condemnation and stigmatisation was thus highlighted, thereby fully reflecting the intentions of the conceivers (the authors) of the Convention.

However, in the light of the case-law of the European Court of Human Rights (hereinafter: ECtHR) and beforehand also of the European Commission of Human Rights (hereinafter: EComHR), going beyond an individual approach and distinguishing between three forms (guises) of prohibited treatment or punishment is justified, on the grounds of Article 3 of the ECHR. ${ }^{5}$

Namely, at a certain point the ECHR's bodies separated torture from inhuman or degrading treatment or punishment, thereby achieving a certain kind of gradation in the forms of treatment or punishment prohibited by Article 3 of the ECHR: from the cruellest and most disgraceful to a milder form, not causing pain and suffering so much as a sense of fear and humiliation. At the same time they introduced the term ill-treatment ${ }^{6}$ to the case-law as a term referring to these three forms of prohibited treatment or punishment. ${ }^{7}$ As such, and considering that in this case it is

\footnotetext{
1 See Art. 3 of the Statute of the Council of Europe. Entry into force: 03 August 1949. CETS No.001: Opening of the treaty: London, 05 May 1949.

2 The dispute over guarantees for these rights became apparent during work of the European Movement International on the ECHR project. See Decaux (1999, p. 6).

${ }^{3}$ It was opened for signature on 20 March 1952 and entered into force on 18 May 1954. One should emphasise that this was the second multilateral treaty concluded by Member States of the CoE.

4 It was added to the ECHR text on the strength of protocol 11, which entered into force on 01 November 1998.

5 However, this contradistinction is not an essential condition for an application to be accepted; besides, applicants frequently word their allegations of the violation of Art. 3 ECHR without indicating a specific form of ill-treatment. This is frequently so in cases related to deportation or extradition - see, inter alia, Ahmed v. Austria, No. 25964/94, 17 December 1996, para. 35; HLR v. France, No. 24573/94, 29 April 1997, para. 30.

6 See, e.g., the EComHR decision in the case of K.H. v. Germany, No. 2004/63, 24 May 1966.

7 See, e.g., Keenan v. United Kingdom, No. 2738/95, 18 January 2001, para. 110; Renolde v France, No. 5608/05, 16 October 2008, \$S 120-121.
} 
about the manner and method of execution, the punishment referred to in Article 3 of the ECHR was recognised as one of the forms of treatment, ${ }^{8}$ though retaining a certain separateness, which is confirmed for instance by the findings of the ECtHR in the case of Tyrer v. UK, 1978. ${ }^{9}$

2. Analysis of the Strasburg case-law reveals that the fundamental division between the prohibited forms of ill-treatment runs between torture and inhuman or degrading treatment or punishment. This dichotomy is of fundamental significance, which is tied to only torture as one of the forms of ill-treatment being given a special stigma, so as to express as fully as possible condemnation for this form of ill-treatment (Cassese, 1993, pp. 225, 256-259). ${ }^{10}$

Such a position was first taken explicite by the ECtHR in $1978^{11}$ in its appraisal of five investigative techniques applied to persons suspected by the British security forces of terrorist activities in Northern Ireland. It stated then that only "deliberate inhuman treatment causing very serious and cruel suffering" could be recognised as torture. ${ }^{12}$

These findings were confirmed in the nineteen-nineties by the Grand Chamber in three successive cases, namely in the case of Aksoy v. Turkey in 1996, ${ }^{13}$ followed by the case of Aydin v. Turkey in $1997^{14}$ and in the case of Selmouni v. France in $1999,{ }^{15}$ thus setting out ruling practice confirmed in subsequent cases, both in "big" ones such as the case of Ilaşcu and others v. Moldova and Russia in $2004,{ }^{16}$ and in individual, though no less important, cases of the type Gäfgen v. Germany in 2010. ${ }^{17}$

As for the two remaining forms of ill-treatment, analysis of the case-law shows that the Court does not set such a sharp boundary between inhuman and degrading treatment. On numerous occasions, when determining whether a specific instance of treatment was in violation of Article 3 of the ECtHR, it has done so without clearly indicating in regard to which of these forms

\footnotetext{
8 Of the most recent cases, see Neshkov and others v. Bulgaria, Nos. 36925/10, 21487/12, 72893/12, 73196/12, 77718/12 and 9717/13, 27 January 2015, s $\int 5226-230$.

9 Regarding degrading punishment, see Tyrer v. United Kingdom, No. 5856/72, 25 April 1978.

10 In this context see the positions of the EComHR members Schermers, Batliner, Vandenberghe and Hall given in the report to the case Warwick v. UK, No. 9471/81, 18 July 1986, p. 5, who warned against too broad interpretation of the concept of torture; a different view was taken by Cassese (1993, p. 225, 256-259).

11 However, in connection with the subject-matter under discussion, the position of a key importance is that taken by the EComHR in the Greek case; see the EComHR report on the case Denmark, Norway, Sweden and the Netherlands v. Greece (Greek case), application nos. 3321/67, 3322/67, 3323/67 and 3344/67, 5 November 1969, p. 186; see Rainey, Wicks, \& Ovey (2014, p. 79).

12 Ireland v. the United Kingdom, complaint no. 5310/71, 18 January 1978, \$167; ultimately, the ECtHR found - with a majority opinion - that the five investigative techniques were not torture, but only inhuman and degrading treatment; five judges submitted separate opinions regarding the judgment; these judges were: M. Zekia, O'Donoghue, D. Evrigenis, F. Matscher and G. Fitzmaurice; while four of these judges considered the techniques torture, according to the judge Fitzmaurice they were not even inhuman and degrading treatment; see in regard to this the remarks by C Rainey, Wicks, \& Ovey (2014,, p. 79) together with the given source literature, including O'Boyle, M. (1977). Torture and Emergency Powers under the European Convention of Human Rights: Ireland v. the United Kingdom. AJIL, 71, 674; D. Bonner, Ireland v. United Kingdom, "ICLO" 1978, Vol. 27, p. 897.

13 Aksoy v. Turkey, No. 21987/93, of 18 December 1996, sS 63-64.

14 Aydin v. Turkey from 1997, No. 23178/94, 25 September 1997, para. 82.

15 Selmouni v. France, No. 25803/94, 28 July 1999, para. 105.

16 Ilaşcu and others v. Moldova and Russia, No. 48787/99, 8 July 2004, IS 424-433.

17 Gäfgen v. Germany, No. 22978/05, 1 June 2010, para. 88 (see the Chamber's findings in the judgment of 30 June 2008 , para. 66); as for the latest cases recognised as the most important for current ruling practice, see inter alia Al Nashiri v. Poland, No. 28761/11, 24 July 2014, Husayn (Abu Zubaydah) v. Poland, No. 7511/13, 24 July 2014, Lyapin v. Russia, No. 46956/09, 24 July 2014; El-Masri v. the Former Yugoslavian Republic of Macedonia, No. 39630/09, 13 December 2012; Habimi and others v. Serbia, No. 19072/08, 3 June 2014; Vladimir Romanov v. Russia, No. 41461/02, 24 July 2008; see also the latest cases from 2015: Ateşoğlu v. Turkey, No. 53645/10, 20 January 2015; and Lolayev v. Russia, No. 58040/08, 15 January 2015.
} 
of ill-treatment Article 3 of the ECHR was violated. ${ }^{18}$ Such a situation occurred for example in the judgment in the case of $M$. and C. v. Romania in 2011, in which the Court found that Article 3 of the ECHR had been violated in connection to acts of sexual abuse committed by the father against the accuser, M. ${ }^{19}$ The ECtHR technique indicated here is applied despite significant differences in the definition of these two forms of ill-treatment..$^{20}$

In the case of Ireland v. the United Kingdom in 1976 the Court defined inhuman treatment as that ". . . were applied in combination, with premeditation and for hours at a stretch; they caused, if not actual bodily injury, at least intense physical and mental suffering." 21 This is evidently not an exhaustive definition, and the catalogue of features and circumstances constituting inhuman treatment remains open.

The above findings show that both in the case of torture and in instances of inhuman treatment, the ECtHR draws attention - though placing the emphasis slightly differently - on the non-accidentalness of these forms of ill-treatment, since in the case of torture it speaks of it being deliberate (Fr. délibéré), and where inhuman treatment says that it was premeditated (Fr. appliqué avec préméditation). One may therefore assume that thorough planning and preparation is required for such treatment.

A certain type of deliberateness is thereby inherent in both definitions, and as such does not seem to constitute an element differentiating these forms of ill-treatment. On the other hand, the intensity of physical or mental suffering (its severity) (Pettiti, Decaux, \& Imbert, 1999, p. 159) inflicted upon the victim is just such a criterion. Torture is of course the most severe form, and as such every form of torture is simultaneously inhuman or degrading treatment. ${ }^{22}$

3. Where degrading treatment is concerned, treatment recognized as such in the case-law is treatment that "arouse(s) in its victims feelings of fear, anguish and inferiority capable of humiliating and debasing them", ${ }^{23}$ while for a specific instance of treatment to be acknowledged as degrading it is sufficient that the feeling of humiliation or debasing was the subjective feeling of the victim ${ }^{24}$ and as such it does not have to be confirmed by third parties. ${ }^{25}$ Moreover, in 1999 the Grand Chamber found that: "... The question whether the purpose of the treatment was to humiliate or

\footnotetext{
18 Such a ruling technique is frequently applied in cases where there is a risk of deportation or extradition, see e.g.: Ahmed v. Austria, No. 25964/94, from 17 December 1996, para. 35; also in cases involving the conditions of detention, see for instance Kupczak v. Poland, No. 2627/09, from 25 January 2011, para. 68.

19 M. and C. v. Romania, No. 29032/04, 27 September 2011; likewise in the case of E. and others v. UK, No. 33218/96, 26 November 2002; Pantea v. Romania, No. 33343/96, 30 June 2003; R.L. and M.-J.D. v. France, No. 44568/98, 19 May 2004; McGlinchey and others v. UK, No. 50390/99, 29 April 2003; sometimes also the ECtHR recognises particular treatment as inhuman or degrading, see e.g. Van der Ven v. the Netherlands, No. 50901/99, 4 February 2003, para. 63.

20 It needs to be pointed out that Art. 3 ECHR does not contain definitions of the forms of ill-treatment analysed. They were defined independently by the ECtHR; however, the ECtHR indicates in its case-law the definition of torture from Art. 1 of the United Nations Convention against Torture.

21 Ireland v. the United Kingdom, 1976, para. 167.

22 See Ilaşcu and others v. Moldova and Russia, 2004, para. 426; likewise e.g. in the ECtHR judgment in the case of Habimi and others v. Serbia, 2014, para. 85, "Torture, however, involves deliberate inhuman treatment causing very serious and cruel suffering. .."; the fragments cited suggest that elements comprising degrading treatment are taken into account in the case of torture.

23 Iwa \czuk v. Poland, 2001, para. 51; Ireland v. the United Kingdom, 1976, para. 167.

24 Ireland v. the United Kingdom, 1976, para. 167.

25 Tyrer v. the United Kingdom, 1978, para. 32.
} 
debase the victim is a further factor to be taken into account . . . but the absence of any such purpose cannot conclusively rule out a finding of a violation of Article 3." 26

As such, in the case of degrading treatment an intention to debase or humiliate the victim is not an essential condition. After all, it is not about the goal the perpetrator was guided by, but the consequence that was or could have been evoked by his action in the victim and other persons. ${ }^{27}$ All the more so since in many cases "breaking the physical or moral resistance" 28 of the victim, or inclining this person to act against their will or conscience, ${ }^{29}$ may be the immediate purpose. The purposes defined above are described in literature dealing with this subject-matter as "prohibited purposes". However, what is significant here is that the Court - unlike in the case of the UN's Convention against Torture - included such purposes not in the definition of torture, but in the definition of degrading treatment, which it has confirmed its relatively more recent cases. ${ }^{30}$

Admitting the subjective feeling of being degraded and humiliated on the one hand while simultaneously abandoning the express requirement for there to be an intention of such treatment on the part of the authorities has significant consequences for the scope of positive obligations for ensuring the conditions for enjoying freedom from degrading treatment while in detention. ${ }^{31}$ This is because the case-law shows that it is possible to determine that the conditions of a person's detention violate the prohibition of degrading treatment even when it has been clearly found that the authorities had no such intention - no such "positive intention". ${ }^{32}$

4. The statement that "separating" the prohibition of torture from the prohibition of inhuman or degrading treatment or punishment made it possible for the Court to significantly broaden the scope of positive obligations linked to the prohibition of ill-treatment will come as no surprise. Besides, this scope is undergoing constant expansion also because the Court consistently refers to the rule of evolutionary interpretation in the process of interpreting these commitments, emphasising that due to the fact that the European Convention is a living instrument, deeds previously recognised as inhuman treatment may, in the future, be acknowledged as torture. ${ }^{33}$

The above finding was referred to by the ECtHR for example in the case of Ilhan $v$. Turkey in 2000, stating that:

Having regard to the severity of the ill-treatment suffered by Abdüllatif İlhan and the surrounding circumstances, including the significant lapse in time before he received proper medical attention, the Court finds that he was a victim of very serious and cruel suffering that may be characterised as torture. . . ${ }^{34}$

\footnotetext{
26 Such was already in the ECtHR judgment in the case $V . v$. the United Kingdom, 24888/94, 16 December 1999, para. 71.

27 T. v. UK, No. 24724/94, 16 December 1999, para. 69.

28 Ireland v. the United Kingdom, 1976, para. 167; of the relatively newer cases, see Dedovskiy and others v. Russia, 2008 , \85.

29 See e.g. the EComHR report on The Greek Case, 1969, p. 186; Keenan v. the United Kingdom, 2001, para. 11; Jalloh v. Germany, 2006, para. 68.

30 Cestaro v. Italy, No. 6884/11, 7 April 2015, para. 190.

31 Peers v. Greece, No. 28524/95, 19 April 2001, para. 74; among the newer cases, see D.G. v. Poland, 2013, \$S 141-177.

32 See Melnik v. Ukraine, No. 72286/01, 28 March 2006, os 110-112.

33 Selmouni v. France, 1999, para. 101.

34 Ilhan v. Turkey, No. 22277/93, 27 June 2000, para. 87.
} 
The severity of the injuries sustained thus became a fundamental criterion for a particular act of ill-treatment to be classified as torture. Analysis of the case-law reveals this rule to have been applied by the ECtHR for example in the case of Korobov v. Ukraine in 2011. The Court found in this case that the injuries sustained by the complainant were sufficiently serious to be characterised as inhuman treatment. However, due to the view that the "increasingly high standard being required in the area of the protection of human rights and fundamental liberties correspondingly and inevitably requires greater firmness in assessing breaches of the fundamental values of democratic societies", they were ultimately deemed sufficiently serious to be treated as torture. ${ }^{35}$

5. A review of the ECtHR's case-law provides the grounds for stating that the ECHR's bodies approach the prohibition in question extremely consistently and emphasise that this multifaceted prohibition expresses one of the fundamental values of a democratic state. ${ }^{36}$ Its main purpose meanwhile is to protect a person's dignity and his physical integrity. ${ }^{37}$ As such it is absolutely binding, ${ }^{38}$ meaning that it cannot be violated ". . . even in the most difficult of circumstances [for a democratic society], such as the fight against organised terrorism and crime. . "39 and a State is not released from the obligation to respect this prohibition by the conduct (behavior, acts) of the victim. ${ }^{40}$ In other words, it is "irrelevant for the purposes of Article 3 ". ${ }^{41}$

The absoluteness indicated in Article 3 of the ECHR has a general dimension, since the ECHR does anticipate any purposes whatsoever that could justify the violation of this article. This applies even to such purposes that have social legitimacy, such as national security, public security, or the economic wellbeing of the country, order and the prevention of crime, health and morality. ${ }^{42}$ This is where the difference lies between the prohibition in Article 3 of the ECHR and the rights guaranteed in Articles 8 to 11 of the ECHR. In regard to the latter, they are rights for which socially recognised goals are a condition for them to be exercised..$^{43}$

This character of the prohibition of ill-treatment has been strengthened by the prohibition of taking measures for the derogation of commitments resulting from Article 3 of the ECHR, even in the case of war or other public danger threatening the life of the nation. ${ }^{44}$ Bearing this in mind,

\footnotetext{
35 Korobov v. Ukraine, No. 39598/03, 21 July 2011, para. 73; see in this context the joint concurring opinion regarding the arguments given by the judges B. Zupančič, I. Berro-Lefèvre and G. Yudkivska.

${ }_{36}$ See e.g. Soering v. UK, No. 14038/88, 7 July 1989, para. 88; Z. and others v. UK, No. 29392/95, 10 May 2001, para. 73; Pretty v. UK, No. 2346/02, 29 April 2002, para. 49.

37 Tyrer v. UK, No. 5856/72, 25 April 1978, para. 33; likewise the EComHR report in the case of East African Asians v. UK, application Nos. 4403/70-4419/70, 4422/70/, 4423/70, 4434/70, 4443/70, 4476/70-4478/70, 4486/70, 4501/70 and 4526/704530/70, 14 December 1973, p. 55, para. 189; also in the ECtHR judgment in the case of Selmouni v. France, No. 25803/94, 28 July 1999, para. 99; among relatively newer cases see for instance the findings in the ECtHR judgments in Afanasyev v. Ukraine, No. 38722/02, 5 April 2005, para. 60; Iwa】czuk v. Poland, No. 25196/94, 15 November 2001, para. 59; Valasinas v. Lithuania, No. 44558/98, 24 July 2001, para. 117.

38 See for instance Ireland v. UK, No. 5310/71, 18 January 1978, para. 163; Raninen v. Finland, No. 20972/92, 16 December 1997; Pretty v. the United Kingdom, 2002, para. 49; Yankov v. Bulgaria, No. 39084/97, 11 December 2003, para. 103.

39 Selmouni v. France, 1999, para. 95; Dedovskiy and others v. Russia, No. 7178/03, 15 May 2008, para. 71; Balogh v. Hungary, No. 47940/99, 20 July 2004, para. 44; Labita v. Italy, No. 26772/95, 6 April 2000, para. 119. [highlighting added]

40 Chahal v. UK, No. 22414/93, 15 November 1996, para. 79.

41 Labita v. Italy, 2000, para. 119.

42 See for instance Art. 8 ECHR.

43 These are indicated in the second sections of Articles 8-11 of the ECHR.

44 See Art. 15 ECHR; as for cases-law, see earlier cases, including: Ireland v. the United Kingdom, 1976, para. 163; Soering v. the United Kingdom, 1989, para. 88; Chahal v. the United Kingdom, 1996, para. 79; Aksoy v. Turkey, No. 21987/93, 18 December 1996,
} 
the ECtHR is successively adding to the scope of Article 3 situations that are increasingly demanding and difficult for this society: from matters of expelling those suspected and sentenced for terrorism, ${ }^{45}$ to matters pertaining to the living conditions of those denied freedom in detention centres, including correctional facilities. ${ }^{46}$

Literature dealing with this subject aptly draws further consequences from the absolute and unconditional character of this prohibition. Firstly, protection against the violation of this prohibition must be as rigorous as possible (with no exceptions); secondly, all doubts regarding its scope must be resolved to the benefit (in favour of) the potential victim; thirdly, potential violators ... may only exercise limited discretion in regard to the content of this right; and fourthly, in the case of ascertaining a violation of this prohibition then compensation must be ensured (Addo, \& Grief, 1998, p. 516). At the same time it must be stressed here that the Court determined that unconditionality and absoluteness refer equally to torture and to inhuman or degrading treatment or punishment. ${ }^{47}$ This approach to Article 3 of the ECHR has been accepted in the literature on the subject (Addo, \& Grief, 1998, p. 512; Evans, \& Morgan, 1998, p. 79).

6. Despite the prohibition of torture, inhumane or degrading treatment or punishment being an unconditional and absolute one, Article 3 of the ECHR does not absolutely prohibit the usage of physical force by State agents, although the latter is admissible in certain strictly defined situations, for example in order to apprehend a person, though only if absolutely essential and commensurate. ${ }^{48}$ Analysis of the case-law shows that these requirements are of particular significance in regard to the conditions of detention. ${ }^{49}$ Moreover, ECtHR case-law suggests that not every instance of treatment or punishment causing physical or mental pain or suffering constitutes a violation of Article 3 of the ECHR. As a result, a State - as a party to the ECHR - does not have the general obligation to protect against every instance of treatment and punishment prohibited by Article 3 of the ECHR. ${ }^{50}$ Treatment or punishment of this kind must reach at least a minimum level of severity in a given situation. ${ }^{51}$ What stands behind this particular idea is the conviction that there are situations immanently connected to a certain level of severity. In the case of violations of commitments resulting from Article 3 of the ECHR this means a level of severity that ". . goes beyond that inevitable element of suffering or humiliation connected with a given form of legitimate treatment or punishment ..."52

para. 62 .

45 Saadi v. Italy, No. 37201/06, 28 February 2008; Chahal v. the United Kingdom, 1996.

46 Kalashnikov v. Russia, No. 47095/99, 15 July 2002.

47 Bekos and Koutropoulos v. Greece, No. 15250/02, 13 December 2005, para. 45.

48 Staszewska v. Poland, No. 10049/04, 3 November 2009, para. 53; Karbowniczek v. Poland, No. 22339/08, 27 September 2011, para. 52 .

49 In regard to the usage of force in conditions of detention, of key significance are the findings in the ECtHR's judgement in the case of Ribitsch v. Austria, 1995, para. 38; among newer cases, see e.g. Sheydayev v. Russia, No. 65859/01, 7 December 2006, para. 59; Dedovskiy and others v. Russia, 2008, para. 73.

${ }_{50}$ See as an example the ECtHR's decision in the case of Tuncer and others v. Turkey, No. 12663/02, 13 June 2003.

51 Costello-Roberts v. UK, No. 13134/87, 25 March 1993, para. 30; newer cases e.g. Opuz v. Turkey, No. 33401/02, 9 June 2009, para. 158; Staszewska v. Poland, 2009, para. 54; Eremia v. Moldavia, No. 3564/11, 28 May 2013, para. 48; Rumor v. Italy, No. 72964/10, 27 May 2014, para. 57.

52 Ireland $v$ the United Kingdom, 1978, para. 162; V.v. UK, No. 24888/94, 16 December 1999, para. 71; see also Kudta v. Poland, No. 30210/96, 26 October 2000, para. 92; Valasinas v. Lithuania, 2001; Jalloh v. Germany, No. 54810/00, 11 July 2006, para. 68; 
The criterion of exceeding the level of suffering or humiliation unavoidable in a specific situation is a central element of the Court's assessment. Suffering inflicted on a victim may involve the infliction of physical or mental suffering. ${ }^{53}$ The assessment of whether the minimum was exceeded is relative, and depends on numerous factors. Some of them are subjective in character, others objective, but they always refer to the specific case in question. Because of this, in certain circumstances the fact of the minimum threshold being exceeded may, on its own, prove insufficient. ${ }^{54}$

Therefore, when analysing the actual state of a specific case in detail, the Court takes into account such circumstances as duration of the ill-treatment, its physical and mental consequences, and - in certain cases - the sex, age and state of health of the victim. ${ }^{55}$ The Court also takes the nature and context of the treatment into consideration. ${ }^{56}$ The above circumstances are taken into account when assessing any of the forms of ill-treatment.

7. Bearing in mind this special nature of human good, the protection of which is addressed by freedom from ill-treatment, it should come as no surprise that among those entitled to exercise this freedom indicated by the ECtHR there is a certain group of people who should be covered by special protection pursuant to Article 3 of the ECHR. These are persons to whom the Court has granted the status of vulnerable individuals, in this case vulnerable to ill-treatment. The protection of people in this category - as a general rule of the obligation to protect connected to ill-treatment. ${ }^{77}$ As aptly noted by Leach (2006), ". . . the Court appears increasingly willing to invoke the positive obligations doctrine in order to scrutinise the frailty and ineffectiveness of domestic laws, particularly to protect vulnerable applicants" (p. 126). Analysis of the case-law suggests that the Court has been doing so consistently since the case of A. vs. the United Kingdom in 1998, in which it emphasised for the first time that: ".. . Children and other vulnerable individuals, in particular, are entitled to State protection, in the form of effective deterrence, against such serious breaches of personal integrity. . ." 58

The Court carried over the idea of protecting vulnerable individuals pursuant to Article 3 of the ECHR from cases in which it investigated accusations of the breaching of physical or psychological integrity in the light of Article 8 of the ECHR, in relation to the sexual abuse of minors by

\footnotetext{
Dedovskiy and others vs. Russia, 2008, para. 72.

53 One of the first cases in which the Court drew attention to mental pain and suffering - Aydin v. Turkey, No. 23178/94, 25 September 1997, para. 83 and 86.

54 The ECtHR decision in the case of O'Rourke v. UK, No. 39022/97, 26 June 2001, The Law para. 2.

55 As in ECtHR judgments in the cases: Price v. UK, No. 33394/96, 10 July 2001, para. 24; Kupczak v. Poland, No. 2627/09, 25 January 2011, para. 58; Jalloh v. Germany, 2006, para. 67; R.R. v. Poland, No. 27617/04, 26 May 2011, para. 148.

56 The importance of the context of ill-treatment is shown by the ECtHR findings in its judgment in the case of Costello-Roberts $v$. the United Kingdom, 1993, in which the ECtHR compared the circumstances of the ill-treatment in this case with the circumstances of such treatment in the case of Tyrer v. the United Kingdom, 1978; analysis of the case-law suggests that the racial context is of particular significance; see inter alia Durđević v. Croatia, No. 52442/09, 19 July 2011.

57 See M. and C. v. Romania, 2011.

58 See A. v. the United Kingdom, No. 25599/94, 23 September 1998, para. 22; among the latest cases see for instance Rumor $v$. Italy, 2014, para. 58.
} 
private persons. ${ }^{59}$ The protection of an individual's physical and psychological integrity is therefore the connecting element in this case. ${ }^{60}$

What is characteristic here is that the Court does not define exactly who falls within this category of people, only explicitly indicating children. ${ }^{61}$ As noted perceptively by Dröge (2003), where children are concerned

... there is a constantly raised need for protection, since children may be harmed in their development and sense of personal dignity to a particular degree and for a particularly long time.... Because of this, the scope of positive obligations here will systematically be slightly greater than in relation to persons of age (p. 324). ${ }^{62}$

The open nature of the catalogue of vulnerable individuals does not seem accidental either. In seeking a common denominator for children and other particularly vulnerable persons, one may presume that the Court has in mind those who, for various reasons, are unable to freely take decisions as most people can. Therefore people are not vulnerable individuals purely because they tend in general to be in a weaker social position, but the weakness of their position, and as such their absence of autonomy, must be the result of a particular relationship of dependence (Dröge, 2003, p. 324). ${ }^{63}$

In addition, whereas in the case of a certain group of vulnerable individuals this relationship of dependence is not so much of a permanent character as one that may endure for longer (children and women as victims of domestic violence, ${ }^{64}$ persons with disabilities or suffering from mental illnesses ${ }^{65}$ asylum-seekers, ${ }^{66}$ the Roma minority, ${ }^{67}$ inhabitants of villages situated in the south-eastern reaches of Turkey during the conflict with PPK guerrillas), ${ }^{68}$ in the majority of cases it is rather of a short-term and transitional character. Because of this the bodies of the ECHR intro-

\footnotetext{
59 A review of ECtHR judgments shows that the Court first referred to expressis verbis for this concept in the case of Stubbings and others $v$. the United Kingdom, 1996, in which the complainants accused the authorities of violating Art. 8 ECHR in relation to acts of sexual abuse, of which they were victims in childhood. The Court stated at that time that "... Sexual abuse is unquestionably an abhorrent type of wrongdoing, with debilitating effects on its victims. Children and other vulnerable individuals are entitled to State protection, in the form of effective deterrence, from such grave types of interference with essential aspects of their private lives. ."; see Stubbings and others v. UK, Nos. 22083/93 and 22095/93, 22 October 1996, para. 64; regarding the protection of physical and psychological protection in the light of Art. 8 ECHR, see e.g. the ECtHR judgment in the case of X. and Y. v. the Netherlands, No. 8978/80, 26 March 1985; in this context also see Bevacqua and S. v. Bulgaria, No. 71127/01, 12 June 2008.

60 Analysis of case-law shows that the concept of vulnerable persons and vulnerable position is also very significant in regard to positive obligations tied to the right to life (Art. 2 ECHR); see for instance Zhebrailova and others v. Russia, No. 40166/07, 26 March 2015, para. 33; and for earlier cases see: Keenan v. the United Kingdom, 2001, para. 91; Salman v. Turkey, No. 21986/93, 27 June 200, para. 99.

61 See the remarks given by Dröge (2003, p. 322-324).

62 See Mubilanzila Mayeka and Kaniki Mitunga v. Belgium, No. 13178/03, 12 October 2006, para. 55 - regarding a small girl from an African country left in Belgium and then sent by that country's authorities without a guardian to her country of origin.

63 See also point 4 of the joint partly dissenting opinion of judges Ziemele and Bianku regarding the ECtHR judgment in the case of Centre for Legal Resources on Behalf of Valentin Câmpeanu v. Romania, No. 47848/08, 17 July 2014.

64 See the remarks by Palmer (2007, p. 69) on the protection of children and women according to Art. 3 ECHR.

65 See the relatively most recent case of M.S. v. Croatia (II), No. 75450/12, 19 February 2015, para. 123.

66 M.S.S. v. Belgium and Greece, 2011, para. 251.

67 V.C. v. Slovakia, No. 18968/07, 8 November 2011, para. 179

68 Akdivar and others v. Turkey, No. 21893/93, 16 September 1996, para. 105; Kurt v. Turkey, No. 24276/94, 25 May 1998, para. 160; Akkoçv. Turkey, Nos. 22947/93 and 22948/93, 10 October 2000, para. 125.
} 
duced the term 'persons in a vulnerable position' into the case-law, ${ }^{69}$ simultaneously emphasising that the authorities are bound by the obligation to protect people in such a situation. ${ }^{70}$

Analysis of the case-law demonstrates that those recognised by the ECtHR as people in such a specific situation are predominantly people in detention ${ }^{71}$ or performing military service, ${ }^{72}$ although for some time now a certain general approach has been noticeable in the position taken by the ECtHR in the light of which "... Article 3 imposes on States a duty to protect the physical well-being of persons who find themselves in a vulnerable position by virtue of being within the control of the authorities ...", while detention and military service is only given as one of the examples of such a situation, ${ }^{73}$ which in turn may be linked to the ECtHR's position from the nineteen nineties, in the light of which the victims of torture are in principle in precisely such a position. ${ }^{74}$

However, the ECtHR's case-law also reveals that the Court does not only talk about vulnerable individuals or about persons who are in a vulnerable position in the context of situations over which a State holds direct control. After all, it dedicates much room to the protection of people from ill-treatment inflicted by private persons, and the entities particularly subject to protection here are children and women.

The preceding remarks constitute a reference to the doctrine of positive obligations that is being rapidly expanded by ECHR bodies. In regard to the prohibition in question, the bodies of the ECHR put a very strong emphasis in their normative justification on the connection that Article 3 of the ECHR has with Article 1 of the ECHR, on the general obligation to respect commitments resulting for States party to the ECHR. Thanks to this, as described by F. Sudre inhérence tous azimuts, positive obligations came to be inseparably connected to the prohibition of torture, and are universally applied (Sudre, 1995, p. 368), while States party to the ECHR expressed their consent to be bound by them at the moment of ratification of the European Convention. ${ }^{75}$

8. Thereby the complexity indicated in the title of this paper does not refer purely to the internal structure of the prohibition of torture (Article 3 of the ECHR), but also to the obligations of States party to the ECHR that are tied to this prohibition. This is because it is not restricted to negative obligations understood as a duty on the part of the State to abstain from certain interferences by the public authorities ${ }^{76}$ and which was the fundamental purpose of the ECHR ${ }^{77}$ and as such was ente-

\footnotetext{
69 See one of the first EComHR decisions in this context in the case of Aksoy v. Turkey, 1994; the decision by the EComHR in the case of Gerrard v. UK, No. 21451/93, 18 October 1995.

70 See for instance the relatively most recent Association for the Defence Of Human Rights in Romania - Helsinki Committee On Behalf Of Ionel Garcea v. Romania, No. 2959/11, 24 March 2015, para. 66.

71 Constitutive significance: Keenan v. the United Kingdom, 2001, para. 91; Dedovskiy and others v. Russia, 2008, para. 73.

72 Cited at this point: Chemberv. Russia, No. 7188/03, 3 July 2008, para. 50; Sarban v. Moldova, No. 3456/05, 4 October 2005, para. 77; Jalloh v. Germany, 2006, para. 69; Mouisel v. France, 2002, para. 40.

73 Denis Vasilyev v. Russia, No. 32704/04, 17 December 2009, para. 115; Premininy v. Russia, No. 44973/04, 10 February 2011, para. 73; also in the case of Aleksandr Novoselov v. Russia, No. 33954/05, 28 November 2013, para. 56.

74 Aksoy v. Turkey, 1996, para. 98; Aydin v. Turkey, 1997, para. 103.

75 Attention is drawn to this by, inter alia, Buergenthal (1965, p. 79).

76 See the partly dissenting opinion to the ECtHR judgment in the case of Marckx v. Belgium, 1979; this was defined similarly by the ECtHR in the judgment in the Belgian linguistic case in 1968, $\$ 31$ : "Court stated in the 'Belgian Linguistic' case, the object of the Article [8_em] is 'essentially' that of protecting the individual against arbitrary interference by the public authorities".

77 ECtHR judgment in the case of Evans v. UK, No. 6339/05, 10 April 2007, \$ 75 “(...) the object of Article 8 is essentially that of protecting the individual against arbitrary interference by the public authorities ..."
} 
red explicite into the normative structure of the freedoms and rights defined in the ECHR, ${ }^{78}$ but embraces - firstly - positive obligations which result in a command to take measures for the purpose of ensuring freedom from the said torture for persons under the jurisdiction of States that are party to the ECHR, both in horizontal and vertical relations, and - secondly - a procedural obligations which, year by year, is achieving an ever more autonomous position among the types of commitment resulting from the ECHR for States ${ }^{79}$ and the essence of which is the effective clarification of circumstances in the violation of the prohibition of torture (Article 3 of the ECHR).

The scope of these obligations for States party to the ECHR determined by the ECHR's bodies fully confirms the fundamental nature of the freedoms protected by Article 3 of the ECHR. ${ }^{80}$

\section{References}

Addo, M. K., \& Grief, N. (1998). Does Article 3 of the European Convention on Human Rights Enshrine Absolute Rights? EJIL, 9(3), 516.

Buergenthal, T. (1965). The Effect of the European Convention on Human Rights on the Internal Law of Member States (I. C. L. Q., Suplmentary Publication No. 11). The British Institute of International and Comparative Law, International Law Series.

Cassese, A. (1993). Prohibition of Torture and Inhuman or Degrading Treatment or Punishment. In Macdonald, R. St. J., Matscher, F., \& Petzold, H. (Eds.), The European System for the Protection of Human Rights. Dordrecht, Boston, London: Martinus Nijhoff Publishers.

Decaux, E. (1999). Les États parties et leurs engagements. In L. E. Pettiti, E. Decaux, \& P. H. Imbert (Eds.), La Convention européenne des droits de l'homme: Commentaire article par article. Paris: Économica.

Dröge, C. (2003). Positive Verpflichtungen der Staaten in der Europäischen Menschenrechtskonvention. Berlin.

Drzemczewski, A. Z. (2001). The Prevention of Human Rights Violations: Monitoring Mechanisms of the Council of Europe. International Studies in Human Rights, 67, 158-163.

Evans, M. D., \& Morgan, R. (1998). Preventing Torture: a Study of the European Convention for the Prevention of Torture and Inhuman or Degrading Treatment or Punishment. Oxford, MS, New York, NY: Clarendon Press Publication.

Leach, P. (2006). Positive Obligations from Strasbourg - Where do the Boundaries Lies. Interights Bulletin. Review of the International Centre for the Legal protection of Human Rights, 15(3), 126.

\footnotetext{
78 ECtHR judgment in the case of $X$ and $Y$ against Holland, No. 8978/80, 26 March 1985, \$\$ 23-24 and 27; the ECtHR decision in the case of August v. UK, No. 36505/02, 21 January 2003; and the ECtHR judgment in the case of Bevacqua and S. v. Bulgaria, No. 71127/01, 12 June 2008, \64.

79 Teren Aksakal v. Turkey, No. 51967/99, 11 September 2007, \$ 69. In this context of key significance is Silih v. Slovenia, No. 71463/01, 9 April 2009, para 159. The case involves the violation by Slovenia of Art. 2 KE in relation to the death in hospital of the complainant's son, which occurred prior to Slovenia's ratification of the KE. However, penal and civil proceedings in this case commenced after the entry into effect of the KE, and they were subjected to ECtHR assessment.

80 For broader information on this topic, see Morawska (2006).
} 
Morawska, E. (2016). Zobowiazania pozytywne państw-stron Europejskiej Konwencji Praw Człowieka. Warsaw.

Palmer, E. (2007). Judicial Review, Socio-Economic Rights and the Human Rights Act, Oxford, MS.

Pettiti, L.-E., Decaux, E., \& Imbert, P. H. (Eds.) (1999). La Convention Europeenne des droits de l'homme: commentaire article par article. Paris.

Rainey, B., Wicks, E., \& Ovey C. (2014). Jacobs, White, Ovey: the European Convention on Human Rights, Oxford: Oxford University Press.

Sudre, F. (1995). Les obligations , positives' dans la jurisprudence européenne des droits de l'homme. Revue trimestrielle des Droits de l'homme.

Data de submissão: 02 de dezembro de 2016 Aceito em: 02 de de dezembro de 2016 